\title{
単形性持続性心室頻拍の不整脈基質：虚血性および 非虚血性心疾患の違い
}

順天堂大学浦安病院循環器内科

中里祐二

持続性心室頻拍 (VT) は虚血性心疾患である心筋 梗塞のほか，拡張型心筋症，肥大型心筋症，催不整 脈性右室心筋症などの非虚血性心疾患でみられる。 いずれにおいても機序は緩徐伝導路を有するリエン トリーと考えられるが，その解剖学的基質は心筋梗 塞と拡張型心筋症では性質を異にする。筋梗塞で は梗塞領域と正常域の境界に存在する曒痕組織周囲 の残存心筋を基盤として心内膜に近い場所でリエン トリー回路が形成され，その際心内膜マッピングでは 緩徐伝導部位の存在を反映して遅延電位や分裂電位 などの異常電位が記録される。それに対し，拡張型 心筋症では心筋のより深い部位や心外膜側に緩徐伝 導部位を有することが多く，心内膜側でのマッピン グでは異常電位が記録されない例も多いとされる1).

里見ら ${ }^{2)}$ は器質的心疾患患者に伴う単形性持続性 VT23例でCARTO システムを用いて心内膜，心外 膜マッピングによる異常電位の同定を行った．陳旧 性心筋梗塞では 8 例中 7 例で心内膜側に瘏痕を認め, そこからの通電でVTが誘発不能になったとしてい る。また心筋症例では 15 例中 13 例で心外膜マッピ ングが必要で，うち 12 例で心外膜からの通電により VTが消失したとしている。 そのなかで，拡張型心 筋症 6 例中 3 例では心内膜，心外膜ともに異常電位 を認めなかったため，心筋のより深部にVTの起源 を有するものと推測している。これらの結果は従来 の報告と一致するが，Hsia ら ${ }^{3)}$ は持続性 VTを伴う 拡張型心筋症のほとんどで左室基部に異常電位が記 録されたと報告しているのに対し，本研究では必ず しもそのような傾向を認めていない. その要因は症
例数の違いも考慮する必要はあるが，おそらく拡張 型心筋症の基質となる心筋組織の瘕痕化・線維化な どの分布が多様であることも関係していると思われ る.とくに心筋内の深部にのみ起源がある場合は心 内膜側，心外膜側いずれからのマッピングでも異常 電位の記録ができず，アブレーションにはペースマ ッピングのみによるアプローチを選択せざるをえな い. 本研究では異常電位が記録できなかった 3 例で 心内膜側からの通電によりアブレーションが成功し ているが, 高周波に比べより効果の高いイリゲーショ ンカテーテルを用いたことも成功の要因と考えられる.

このように虚血性VTでは心内膜側に基質が存在 することが多く, 心内膜アプローチでのアブレーショ ン治療が可能である。それに対し非虚血性VTの場 合には心外膜側に基質を有する例が多いため，アブ レーションの成功率を高めるためには心外膜アプロー チを試みる必要性や，心筋深部起源により効果的な アブレーションを行う方法を検討する必要がある。 今後，本邦においてもイリゲーションカテーテルの 早期承認・導入が望まれるところである.

\section{〔文献〕}

1 ) Soejima K, Stevenson WG, Sapp JL, Selwyn AP, Couper G, Epstein LM : Endocardial and epicardial radiofrequency ablation of ventricular tachycardia associated with dilated cardiomyopathy: the importance of low-voltage scars. Journal of the American College of Cardiolgy, $2004 ; 43: 1834 \sim 1842$

2 ）里見和浩, Feifon Ouyang, Roland Tiltz, 高月誠二, 
Dietmar Bansch, 鎌倉史郎, 友池仁暢, Karl-Heinz Kuck：単形性持続性心室頻拍を伴う器質的心疾患患者 における心内膜および心外膜マッピングの特徵一虚血性 および非虚血性心疾患との比較－。心電図，2008； $28: 158 \sim 166$
3 ) Hsia HH, Marchinski FE : Characterization of the electroanatomic substrate for monomorphic ventricular tachycardia in patients with nonischemic cardiomyopathy. Pacing Clin Electrophysiol, 2002 ; 25 : $1114 \sim 1127$ 